\title{
Determining Factors Of Long-Term Orientation Of Firm-Supplier Relationships: An Empirical Analysis In The Context Of The Spanish Agro-Food Sector
}

Jesús J. Cambra Fierro, (Email: jjcamfie@ upo.es), University of Pablo de Olavide - Sevilla, Spain Yolanda Polo Redondo, (Email: ypolo@ unizar.es), University of Zaragoza, Spain

\begin{abstract}
In an increasingly competitive and dynamic economic environment, the establishment, development and maintenance of enduring relationships between suppliers and customers is critical for both agents, and represents an important source of competitive advantages for those companies able to manage them adequately. Taking as reference the perspective of the customer, we consider that it is important for them to always work with a group of suppliers that have demonstrated an ability to adapt to their specific needs and thereby to reduce the level of uncertainty associated with their supply function. The current work, which takes the Spanish agro-food sector as framework of reference, analyzes the importance of certain factors in the long-term orientation of these relationships.
\end{abstract}

\section{INTRODUCTION}

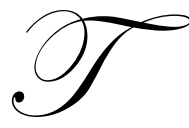

he long-term orientation of commercial relationships - both with suppliers and with customers - has become a basic element for many company managers. The intention of these economic agents is to create and deliver satisfaction so that all the parties involved have an interest in maintaining and strengthening the existing relationship ties. Thus, their objective is to establish, develop and maintain stable and lasting relationships between buyers and sellers, such that both parties benefit (Grönroos, 2000; Kothandaraman and Wilson, 2001; Sharma et al., 2001; Walter et al., 2001; Leek et al., 2003). The buyer's satisfaction and loyalty become the key element for the suppliers, and together with their own profitability, guarantee mutual interest in the relationship and its continuity over time. In parallel, firms have an interest in maintaining lasting supply relationships with suppliers that have demonstrated the ability to adapt to their needs.

In this way the relationships become a source of mutually beneficial competitive advantages (Walter et al., 2003), which are sustainable and defensible (Turnbull and Wilson, 1989), for companies able to manage them adequately, either internally or externally. The long-term orientation of these exchange relationships represents the best means of attracting the other party and keeping them satisfied, and it is more important the greater the value generated for both agents (Grönross, 1996). Relationship marketing tries to orient firms towards the employment of their resources and capabilities to create and deliver greater value to their co-participants, through the establishment of long-term relationships with them (Grönroos, 2000; Rexha, 2000; Van der Haar, Kemp and Omta, 2001).

Taking the current reality of industrial markets as reference (Brennan and Turnbull, 1999; Leek et al., 2003), we see that in this context relationship marketing, and by extension the long-term orientation of the relationships, becomes even more important. From the perspective of the supplier the aim is to reap the benefits of all the efforts, in terms of financial resources and time, previously exerted to win the customer, while this latter is interested in working with a group of suppliers that have previously demonstrated their capability. 
Some of the most relevant work in the discipline considers that satisfaction (Anderson and Narus, 1990; Siguaw et al., 1998; Cannon and Perrault, 1999; Walter et al., 2003) and commitment (Dwyer et al., 1987; Moorman et al., 1992; Kim and Frazier, 1997; Jap and Ganesan, 2000) represent the fundamental concepts that determine the long-term orientation of the relationship. In other words, the result achieved (Mohr et al., 1994) and the intention to maintain the relationship (Morgan and Hunt, 1994; Garbarino and Johnson, 1999).

Thus, the main objective of our study is to analyze, from the customer's perspective, the significance of these two factors - satisfaction and commitment - in the temporal orientation of industrial customers' supply relationships. Furthermore, we consider the influence of a set of elements as antecedents of the level of satisfaction and/or commitment: trust; level of cooperation; and communication.

With this purpose, we present an empirical study in the Spanish agro-food sector, analyzing the relational orientation of the supply function in a random sample of companies. The heterogeneity of these companies in terms of their size, ownership structure, managers' educational background and experience, among other elements, along with the socio-economic importance of the sector in the Spanish economy, reinforce the value of this research.

Finally, we highlight the implications that can be drawn from our study, and suggest possible lines of research for the future.

\section{THEORETICAL FRAMEWORK AND HYPOTHESIS OF EMPIRICAL RESEARCH}

The basic framework of reference for this study is the so-called relationship marketing. In this respect, and in order to deepen our understanding of the main concepts, we have referred to some of the most relevant studies in the area.

The commercial relationships established between a firm and its suppliers are more or less closed (Hunt et al., 1989; Leuthesser, 1997; Rexha, 2000) and complex, and they are determined by a large number of factors that interact and determine their conditions and outcomes (Morgan and Hunt, 1994; Grönroos, 2000). Furthermore, these relationships are dynamic, develop and evolve over time (Ford, 1980; Kohli and Leuthesser, 1995; Wilson, 1995; Leuthesser, 1997; Johnson, 1999; Tuten and Urban, 2001; Lemon et al., 2002).

Companies that develop more closed relationships can benefit from cost reductions and/or raised revenues, and their exchanges are less risky and uncertain (Ford, 1980).

Supplier and customer interrelate as two active parties and they adapt to each other to a certain extent. Hence interactive relationships emerge (Gummensson, 1987; Grönroos, 2000). Moreover, if high potential benefits are perceived to result from the relationship, specific investments will be made in order to consolidate it and achieve a greater adaptation (Hallen et al., 1991; Morgan and Hunt, 1994; Donney and Cannon, 1997). This fact will also be regarded as an indicator of the level of relationship commitment (Morgan and Hunt, 1994).

The relationship process evolves from identifying potential suppliers to establishing and maintaining the relationship. The firm's ability to administer and manage the elements determining a relationship (Heide, 1994; Grönroos, 2000), and the satisfaction that the agents obtain or expect to obtain (Hogan, 2001; Walter et al., 2003), become critical elements that determine the long-term orientation of the relationship.

The objective of this work is to analyze how satisfaction and commitment affect the long-term orientation of commercial relationships, and also to examine the indirect effects of trust, collaboration, and communication.

\section{Communication}

This variable can be understood as the degree to which partners of a relationship exchange meaningful and timely information (Anderson and Narus, 1990; Anderson and Weitz, 1992). It is composed of aspects such as the 
frequency, mode, direction, quality, and participation (Mohr and Nevin, 1990; Mohr and Spekman, 1994; Mohr and Sohi, 1995).

There are sometimes high levels of uncertainty (Achrol and Stern, 1988) generated by the complexity and heterogeneity of the products or environment, and by the rate of change in the market and in the demand (Geykens et al., 1998). There can also be problems of asymmetric information. Thus, the exchange of personal or impersonal information and its degree of formalization represents a key element in the dynamics of commercial relationships (Anderson et al., 1994; Kalafatis, 2002).

The exchange of information influences the fluidity of the relationship, making both the customer's needs and the supplier's capabilities known (Dwyer et al., 1987; Anderson and Narus, 1990; Geykens et al., 1998). It is also a necessary tool to resolve any doubts or conflicts that may arise in the course of the relationship (Anderson et al., 1994; Kalafatis, 2002), bringing agents' expectations and subsequent perceptions closer together (Hogan, 2001; Lemon et al., 2002), and strengthening mutual knowledge and therefore increasing trust (Wilson, 1995; Jap and Ganesan, 2000). For Mohr and Nevin (1990), communication is the key variable for achieving positive results in a relationship.

Hypothesis 1: The costumer's level of trust is positively and directly influenced by the level of communication with its supplier.

Hypothesis 2: The level of satisfaction perceived by the customer is positively and directly influenced by the level of communication with its supplier.

\section{Customer Trust As Antecedent Of Cooperation, Level Of Perceived Satisfaction And Degree Of Relationship Commitment}

We can say that trust exists when one party has faith in the other - i.e., it accepts the word and signals of the other participant in the relationship (Moorman et al., 1992; Morgan and Hunt, 1994; Donney and Cannon, 1997; Atuathene-Gima and Li, 2002). Trust is associated with the consistency of the suppliers' past actions and image that form its reputation.

When an agent trusts the other party, it does not undertake actions or make decisions that negatively affect them (Anderson and Narus, 1990; Atuathene-Gima and Li, 2002). The agents do not behave opportunistically, and moreover desire that the other party perceives this to be the case (Ganesan, 1994). When both agents trust in the relationship they can invest resources and efforts in committing themselves mutually and they will cooperate (Morgan and Hunt, 1994). Thus, trust facilitates more effective and efficient relationships, directly affecting the outcomes and hence the satisfaction achieved (Dalhlstrom and Nygaard, 1995; Siguaw et al., 1998; Handfield and Bechtel, 2002), as well as the customer's degree of commitment to the relationship.

The uncertainty that can be generated by ignorance of the supplier can negatively affect the customer's level of trust (Ford, 1980; Sharland, 2001). When mutual ignorance is acute (Hansen et al., 1996) trust plays a much more important role in the customer's perceived satisfaction and degree of commitment to its supplier. In this way, trust also reinforces cooperation (Morgan and Hunt, 1994).

Hypothesis 3: The level of cooperation is positively and directly influenced by the level of trust in its supplier.

Hypothesis 4: The level of satisfaction perceived by the customer is positively and directly influenced by the level of trust in its supplier.

Hypothesis 5: The level of relationship commitment is positively and directly influenced by the customer's level of trust in its supplier.

\section{Influence Of Collaboration On Level Of Perceived Satisfaction}

In the relationship marketing literature collaboration is regarded as a basic variable of reference (Anderson and Narus, 1990; Dabholkar et al., 1994; Morgan and Hunt, 1994; Wilson, 1995), especially if we consider the group 
of direct antecedents of the level of satisfaction perceived by the customer (Geykens et al., 1998; Cannon and Perrault, 1999). This variable refers to the mutual cooperation that exists between supplier and customer (Anderson and Narus, 1990; Crosby et al., 1990). Thus, in a context of corporation the agents resolve together problems caused by the evolution of the relationship itself, or develop common projects (Anderson and Narus, 1990; Crosby et al., 1990; Andaleeb, 1995; Hewett et al., 2001), strengthening the relationship and raising the level of mutual satisfaction (Geykens et al., 1998), both in economic and psychological terms.

Hypothesis 6: The level of satisfaction perceived by the customer is positively and directly influenced by the level of cooperation with its supplier.

\section{Level Of Satisfaction Perceived By Customer}

The success of a long-term relationship is a multi-dimensional concept made up of an objective facet of the results obtained and another affective dimension (Mohr and Spekman, 1994), referring to the perception of the degree to which the expectations created have been met. $\mathrm{Li}$ (1998) proposes that the result obtained can be measured in function of the degree to which a channel member perceives the relationship to be effective, productive and satisfactory, and furthermore, influences the long-term orientation of the relationship. If we look at the work of Wilson (1995), Tikkanen et al. (2000) and Lemon et al. (2002), for a firm to orient its supply relationships towards the long-term, the perceived real value should be positive, so that the switching costs rise. The relationship must be useful and help the firm achieve its objectives. Once the customer has verified the supplier's real capability of satisfying its needs, it will consider the risk and uncertainty that any change in the supply decision would imply, a fact that decisively shifts the balance from a transactional-type orientation to a relational one.

Hypothesis 7: The long-term orientation of the relationship is positively and directly influenced by the degree of satisfaction obtained by the costumer.

Hypothesis 8: The level of relationship commitment is positively and directly influenced by the degree of satisfaction obtained by the costumer.

\section{Effect Of Relationship Commitment}

Relationship commitment is considered within the marketing literature as a critically important element for the success of long-term relationships and their long-term orientation. This is reflected in the work of Gundlach et al. (1995), Geykens et al. (1998) and Jap and Ganesan (2000), among others. In this respect, commitment is one of the most widely-used variables in research into buyer-seller relationships (Dwyer et al., 1987; Moorman et al., 1992; Kim and Frazier, 1997; Jap and Ganesan, 2000). The concept of commitment represents the enduring desire to maintain a relationship, and reflects an attitude and behavior with respect to the long-term orientation of the relationship (Morman et al., 1992; Morgan and Hunt, 1994).

Commitment has a dual attitudinal and behavioral dimension. On the one hand, it reflects an attitude, belief, desire or promise of continuity (attitude) (Moorman et al., 1992), in which the agent is prepared to exert a particular effort (behavior) (Wilson, 1995; Andaleeb, 1996) to orient the relationship towards the long-term (Moorman et al., 1992; Morgan and Hunt, 1994; Wilson, 1995; Andaleeb, 1996).

For Gundlach et al. (1995) and Geykens et al. (1998) commitment is the enduring intention to develop and maintain a long-term relationship. Kumar et al. (1995a, b) analyze commitment from the perspective of one of the relationship partners, considering their intention to continue the relationship. Jap and Ganesan (2000) propose that given that both parties - supplier and customer - act in the interests of the relationship, it will be easier to achieve mutual objectives and that the relationship be oriented towards the long-term, developing and maintaining a stable and enduring relationship.

Hypothesis 9: The long-term orientation of the relationship is positively and directly influenced by the level of commitment shown by the customer. 
Therefore, our model proposes analyzing the long-term orientation of supply relationships taking as reference the previously explained hypothesis. This model is shown in figure 1 .

Figure 1: Conceptual model

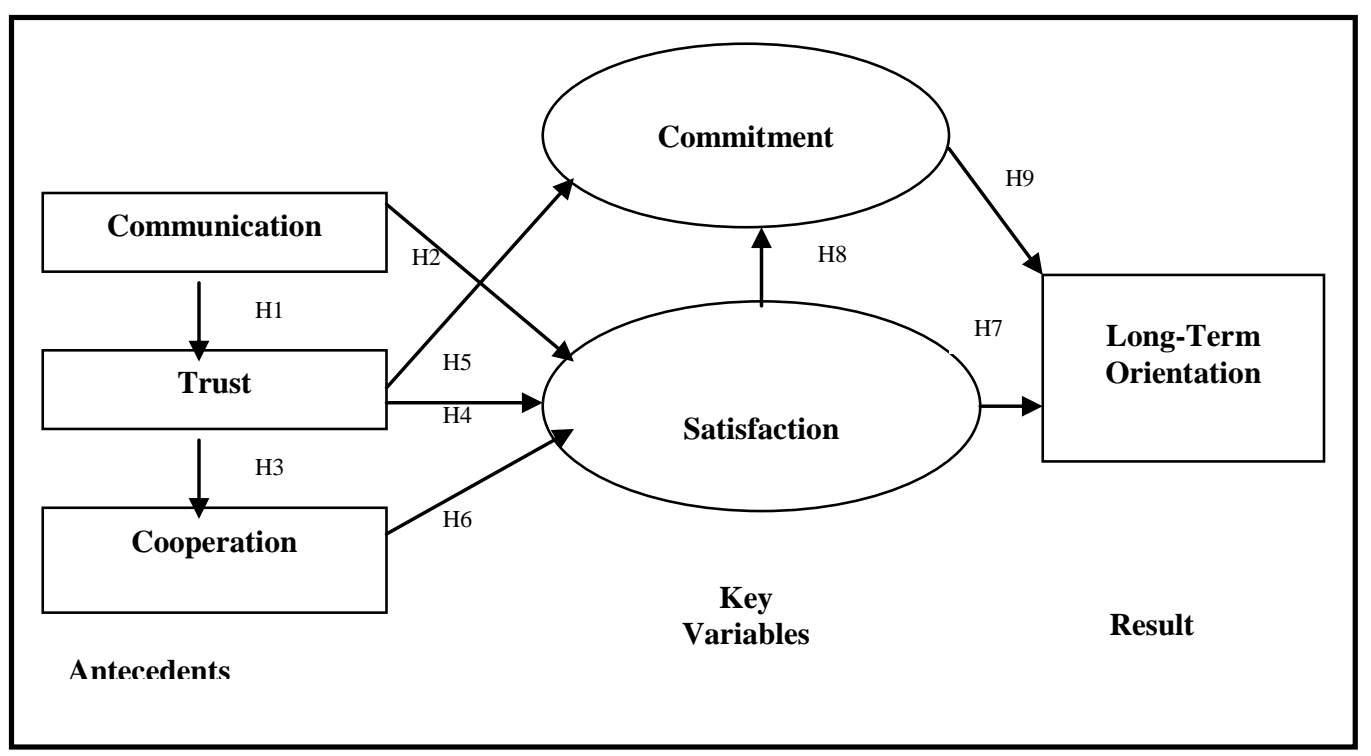

\section{METHODOLOGY}

\section{Data Collection}

The information was obtained by means of a postal survey of managers responsible for the supply function from a random sample(1) of Spanish agro-food companies, specifically wine producers. The reason for approaching these professionals was to obtain responses from individuals directly in contact with the firm's suppliers, and who negotiate the purchasing agreements.

Of the total of 650 questionnaires sent, 159 were returned, of which we eliminated 5 for having missing data and 1 for duplicated responses in various items. The 153 questionnaires finally obtained represents $23.53 \%$ of the total number of questionnaires distributed, for which we can consider our sample to be representative of the population object of study(2). Table 1 presents the technical specifications of the study. Data were analyzed using the EQS software (5.7b).

Table 1: Technical Specifications Of Study

\begin{tabular}{||l|l||}
\hline Universe & Winery managers responsible for supply function \\
\hline Geographical Scope & National - Spain \\
\hline Sample & 153 winery-supplier relationships \\
\hline Sampling Method & Simple random \\
\hline Sample Error & $8,06 \%$ \\
\hline Confidence Level & $95 \% ; \mathrm{p}=\mathrm{q}=0.5$ (if $\mathrm{z}=1.96 \%)$ \\
\hline Data Collection & Postal survey \\
\hline Fieldwork & November $2003-$ May 2004 \\
\hline
\end{tabular}




\section{Measurement Scales}

The questionnaires were fundamentally made up of questions inquiring about the demographic characteristics of the wineries, the type of input and supplier analyzed, and aspects relating to the level of trust in this supplier, cooperation, communication, degree of perceived satisfaction, level of commitment to the relationship, and finally the degree of long-term orientation of the relationship (Appendix 1).

Therefore we considered various multi-item scales adapted from other previous works, which are described in Appendix 1. The items finally used are the result of a previous exploratory study carried out through five personal interviews with managers from some of these companies and a small pre-test, aimed at quantifying the size of the questionnaire and clarifying the terms employed. Therefore, although these previous scales were our main reference we can consider our scales as new ones.

With regards the communication, we wished to measure its quality, taking into consideration its frequency, nature, degree of formalization, direction, and relevance. The scale proposed was adapted from the ones built by Mohr et al. (1996) and Cannon and Homburg (2001).

The trust scale reflects the level of trust the customer has in its supplier. Starting from the proposals by Ganesan (1994), Siguaw et al. (1998), Sharland (2001), and Walter et al. (2003), adapted to the specific characteristics defining our sector of reference, we used five items capturing the firm's perception of its supplier's image, sincerity, and concern, as well as its trust in the supplier strictly speaking. Although some relevant previous works recognize trust as a multidimensional concept we bit for an one-dimensional scale that contains only the concepts we needed. The recommendations of Baumgartner and Homburg (1996) have been followed.

The scale for cooperation is composed of only two items analyzing the type and level of collaboration existing between the wineries and their suppliers. We used the scale proposed by Cannon and Perrault (1999) as reference, which simultaneously considers the concepts of collaboration and joint resolution of potential conflicts to measure the level of relational collaboration. Although Nunnally and Bernstein (1994) argue that considering only 2 items could reduce the explicative power of the scales, Baumgartner and Homburg (1996) accept scales with al least 2 items if reliability is achieved. Our pre-test recommended this scale and it is reliable (see table 3 ).

With regards the scale proposed to measure the level of perceived satisfaction, we did not distinguish between economic and psychological satisfaction, but instead measure the relationship in global terms and with respect to the expectations formed in its initial stage. After reviewing the most relevant literature we developed a scale mixing new indicators with other measures proposed in the work of Anderson and Narus (1990) and Walter et al. (2003).

The 4 items used in the commitment scale were adapted from the scales proposed by Siguaw et al. (1998), Jap and Ganesan (2000), De Wulf et al. (2001), Sharland (2001), and Walter et al. (2003). This is a scale capturing diverse dimensions of commitment: readiness to invest in the relationship; expectations of continuity, maintaining or increasing the volume purchased from the supplier; and attitude towards the terms agreed with the other party, either verbally or in writing.

Finally, to measure the long-term orientation of the relationship we took the scales proposed by Heide and Johnson (1990), Ganesan (1994), and Johnson (1999) as reference. This scale measures the utility of the long-term relationship for the customer and its expectations of continuity in the future, and consists of three items: benefits; importance; and objectives. 
Table 2: Measuring Scales; Validity Of Content

\begin{tabular}{||l|l||}
\hline Measuring Scales & Sources \\
\hline Trust & Ganesan (1994), Siguaw et al. (1998), Sharland (2001), Walter et al. (2003) \\
\hline Cooperation & Cannon y Perrault (1999) \\
\hline Communication & Mohr et al. (1996), Cannon y Homburg (2001) \\
\hline Satisfaction & Anderson y Narus (1990), Walter et al. (2003) \\
\hline Commitment & Jap y Ganesan (2000), De Wulf et al. (2001), Sharland (2001), Walter et al. (2003) \\
\hline Long-Term Orientation & Ganesan (1994), Johnson (1999) \\
\hline
\end{tabular}

\section{Validation Of Measurement Scales}

We first established one model to measure the relations between the constructs (structural model), and another to measure the relations between these constructs and the observable variables (measurement model). In the estimation of the model we opted to use the robust maximum likelihood method (Bentler, 1995), which allows the model to violate univariate normality. This is moreover an appropriate method of estimation for samples between 100 and 150 cases (Hair et al., 1999).

Once the data was tabulated, we refined and validated the measurement scales proposed. Thus, we followed the methodology proposed by Churchill (1979) and Anderson and Gerbing (1988), evaluating the psychometric properties of these scales: unidimensionality; validity; and reliability.

We first verified that all the scales were unidimensional. Then, to evaluate the internal consistency we used the item-to-total correlation (Anderson and Gerbing, 1988), and simultaneously ran a principal components exploratory factor analysis (Bentler and $\mathrm{Wu}, 1995)$. The refinement process consisted of eliminating indicators presenting a low item-to-total correlation(3) (Bagozzi, 1981), as well as those with very low factor loadings. In the commitment scale we eliminated factor CM4, which has a factor loading of 0.2 , and an item-to-total correlation of 0.1018 .

Subsequently, we ran a confirmatory factor analysis using structural equations (Anderson and Gerbing, 1988) with the EQS program (Bentler, 1995), applying the maximum likelihood method. The results obtained are highly satisfactory: $\chi^{2}$ Sat. $=48,592(\mathrm{p}<0,01)$; RMR $=0,53$; RMSEA $=0,039$; NFI= 0,948; NNFI=0,951; AGFI= 0,927; CFI= 0,967 ; IFI $=0,959$; Normed $\chi^{2}=1,59$. Table 3 reports the factor loadings. Following the recommendation of Baumgartner and Homburg (1996), in order to test the model identification, we include the variance and co-variances matrix (See appendix 2).

Measurement scale reliability was evaluated using the statistics Cronbach alpha $(>0,8)$ (Nunnally, 1979), composite reliability index $(>0,7)$, and variance extracted $(>0,5)$ (Hair et al., 1999). As can be seen in Table 3, the scales are reliable for all the statistics, insofar as they exceed the optimal values recommended.

Each indicator's estimated pattern coefficient on its posited underlying construct is significant, which suggests the convergent validity of each factor (Anderson and Gerbing, 1988; Iglesias and Vázquez, 2001). In order to assess the discriminant validity we calculated the test of $\square^{2}$ differences. For every pair of factors, the $\square^{2}$ value for the model that constrained the correlation to equal 1 was significantly greater $(p<0,01)$ than the $\square^{2}$ value for the model that did not place such constraint (Table 5). This is enough evidence of discriminant validity (Anderson and Gerbing, 1988; Hair et al., 1999). 
Table 3: Confirmatory Factor Analysis

\begin{tabular}{||c|c|c|c|c|c||}
\hline Construct $\left(\mathbf{F}_{\mathbf{x}}\right)$ & & $\begin{array}{c}\text { Non-Std. Factor } \\
\text { Loadings }\end{array}$ & T-Values & $\begin{array}{c}\text { Std. Factor } \\
\text { Loadings }\end{array}$ & $\begin{array}{c}\text { Individual } \\
\text { Reliability } \\
\text { Coefficient }\end{array}$ \\
\hline Trust (F1) & T1 & 0,690 & 5,802 & 0,569 & 0,537 \\
\hline & T2 & 0,574 & 4,876 & 0,584 & 0,541 \\
\hline & T3 & 0,989 & 14,452 & 0,981 & 0,963 \\
\hline Cooperation (F2) & T4 & 0,620 & 10,080 & 0,819 & 0,671 \\
\hline & Cp1 & 0,623 & 6,972 & 0,752 & 0,565 \\
\hline Communication (F3) & CP2 & 0,692 & 11,353 & 0,971 & 0,942 \\
\hline & Inf1 & 0,860 & 7,513 & 0,712 & 0,517 \\
\hline INF2 & 0,904 & 4,958 & 0,888 & 0,788 \\
\hline Satisfaction (F4) & INF3 & 0,896 & 6,736 & 0,684 & 0,586 \\
\hline & S1 & 0,561 & 9,186 & 0,842 & 0,710 \\
\hline & S2 & 0,670 & 5,651 & 0,753 & 0,568 \\
\hline Sommitment (F5) & S4 & 0,582 & 8,433 & 0,763 & 0,582 \\
\hline & Cm1 & 1,024 & 10,284 & 0,924 & 0,547 \\
\hline & CM2 & 0,541 & 4,790 & 0,676 & 0,654 \\
\hline Long-Term Orientation (F6) & CM3 & 0,636 & 8,214 & 0,693 & 0,580 \\
\hline & Or1 & 0,927 & 12,161 & 0,982 & 0,964 \\
\hline
\end{tabular}

Table 4: Reliability Of Measuring Scales

\begin{tabular}{||l|c|c|c|c|c|c||}
\hline \hline Estimator & Trust & Cooperation & $\begin{array}{c}\text { Communica- } \\
\text { tion }\end{array}$ & Satisfaction & Commitment & $\begin{array}{c}\text { Long-Term } \\
\text { Orientation }\end{array}$ \\
\hline Cronbach $\alpha$ & 0,8827 & 0,9321 & 0,8765 & 0,909 & 0,9167 & 0,9383 \\
\hline Composite Reliability & 0,8015 & 0,8422 & 0,7976 & 0,8378 & 0,8574 & 0,8623 \\
\hline $\begin{array}{l}\text { Average Variance } \\
\text { Extracted }\end{array}$ & 0,559 & 0,572 & 0,553 & 0,5721 & 0,5637 & 0,6548 \\
\hline
\end{tabular}

Table 5: Analysis Of Discriminant Validity; Test Of $\chi^{2}$ Differences

\begin{tabular}{||c|c|c||}
\hline Pares & $\chi^{2}$ Difference Test $($ D.F.=1) & P-Value \\
\hline F1, F2 & 122,7973 & 0,000 \\
\hline F1, F3 & 395,7593 & 0,000 \\
\hline F1, F4 & 81,4753 & 0,000 \\
\hline F1, F5 & 60,7783 & 0,000 \\
\hline F1, F6 & 341,2433 & 0,000 \\
\hline F2, F3 & 123,9093 & 0,000 \\
\hline F2, F4 & 52,1963 & 0,000 \\
\hline F2, F5 & 30,0043 & 0,000 \\
\hline F2, F6 & 100,9963 & 0,000 \\
\hline F3, F4 & 84,0273 & 0,000 \\
\hline F3, F5 & 54,4673 & 0,000 \\
\hline F3, F6 & 228,6323 & 0,000 \\
\hline F4, F5 & 37,5313 & 0,000 \\
\hline F4, F6 & 89,2873 & 0,000 \\
\hline F5, F6 & 48,8023 & 0,000 \\
\hline \hline
\end{tabular}




\section{RESULTS}

After validating our measuring scales the hypothesis included in our model were tested. Our data show that all the causal relations proposed are significant, at a $1 \%$ level of significance, were standard deviations fluctuate between 0,449 and 0,605. Results are shown in Table 6 .

Therefore, these data reflect that, as we predicted in our hypothesis, there is a significant relation between communication and trust $(\mathrm{H} 1)\left(\lambda_{\text {est }}=0,531 ; \mathrm{p}<0,01\right)$. When communication is present, satisfaction arises $(\mathrm{H} 2)$ $\left(\lambda_{\text {est }}=0,651 ; \mathrm{p}<0,01\right)$. Respect to trust, analyzing our data we are able to demonstrate that it could be considered as significant antecedent of cooperation (H3) $\left(\lambda_{\text {est }}=0,476 ; \mathrm{p}<0,01\right)$, satisfaction (H4) $\left(\lambda_{\text {est }}=0,595 ; \mathrm{p}<0,01\right)$ and commitment (H5). ( $\lambda_{\text {est }}=0,664 ; \mathrm{p}<0,01$ When firms and suppliers cooperate, satisfaction higher $(\mathrm{H} 6)\left(\lambda_{\mathrm{est}}=0,627\right.$; $\mathrm{p}<0,01)$. If customers are satisfied by suppliers, they will orientate relationships to the long-term $(\mathrm{H} 7)\left(\lambda_{\text {est }}=0,701\right.$; $\mathrm{p}<0,01)$ and they will be more committed to these suppliers (H8) $\left(\lambda_{\text {est }}=0,449 ; p<0,01\right)$. Finally, our model proposed a direct relation between commitment and long-term orientation of supply relationships (H9) $\left(\lambda_{\text {est }}=0,597 ; p<0,01\right)$. We can observe that it is also significant.

Table 6: Test Of Hypothesis

\begin{tabular}{|l|c|c|c||}
\hline Model & Standardized Parameters & T-Value & Hypothesis \\
\hline Communication-Trust & $0,531^{\mathrm{A}}$ & 3,142 & H1: Yes \\
\hline Communication-Satisfaction & $0,651^{\mathrm{A}}$ & 5,743 & H2: Yes \\
\hline Trust-Cooperation & $0,476^{\mathrm{A}}$ & 2,781 & H3: Yes \\
\hline Trust-Satisfaction & $0,595^{\mathrm{A}}$ & 4,214 & H4: Yes \\
\hline Trust-Commitment & $0,664^{\mathrm{A}}$ & 5,954 & H5: Yes \\
\hline Cooperation-Satisfaction & $0,627^{\mathrm{A}}$ & 4,433 & H6: Yes \\
\hline Satisfaction-Long Term Orientation & $0,701^{\mathrm{A}}$ & 6,712 & H7: Yes \\
\hline Satisfaction-Commitment & $0,449^{\mathrm{A}}$ & 4,386 & H8: Yes \\
\hline Commitment-Long Term Orientation & $0,597^{\mathrm{A}}$ & 4,478 & H9: Yes \\
\hline
\end{tabular}

A.-Significant for a $99 \%$ level

The data for the long-term orientation of supply relationships result in a $\mathrm{R}^{2}=0,723$. More than $70 \%$ of its variance could be explained by the direct effect of satisfaction and commitment plus the indirect effect of communication, trust and cooperation. Thus, the model is capable of explaining the long-term orientation of companies' supply relations, on the basis of the direct effects of satisfaction and commitment, added to the indirect effects of communication, trust and cooperation.

With regards the goodness of fit of the model, the results show a reasonable fit between the multi-sample model and the data: GFI=0,936; RMR=0,041; RMSEA=0,047; NNFI=0,946; CFI=0,960; IFI=0,963; Normed $\chi^{2}=$ 1,86 .

\section{CONCLUSIONS: IMPLICATIONS FOR MANAGEMENT}

Our model shows that in the context of the Spanish agro-food sector, satisfaction and commitment are fundamental factors when we analyze the possible long-term orientation of the relationships that companies establish with their suppliers. In addition, as immediate antecedents we find that trust in the supplier, mutual cooperation and communication explain a large part of the level of satisfaction perceived by the customer and their commitment to the relationship. For this reason, companies interested in establishing and maintaining enduring relationships with their customers should pay close attention to the management of these elements as generating factors of satisfaction. They should always be able to differentiate themselves with respect to their competitors, showing an interest in the continuity of the relationship. In this way these elements will become fundamental factors in the administration of customer portfolios in firms committed to a relationship orientation. 
These conclusions have some implications for managers responsible for customer relationships, in the context of industrial markets in general, and the agro-food sector in particular. First, firms positively value the relational orientation of their supply function, since it also reduces the level of uncertainty associated with their choice of supplier. In addition, it leads to an important saving in resources that can be dedicated to other tasks.

For this, a fluid exchange of information between both supplier and customer is fundamental. We recognize then that there is a bi-directional process in which the supplier is perhaps the agent that must exert most effort. Thus, the objective of companies should be to design a system guaranteeing a frequent and effective personal level of contact with their customers, which is capable of adapting to possible changes in the environment that define the relationship. If there is a fluid exchange of meaningful information in both directions, we can expect the customer to trust its supplier, and its perceived satisfaction will grow.

With regards trust, this generally depends on the perceived behavior and not only on the promises made. The image that the customer has of its supplier is fundamental at the beginning of the relationship, while the behavior observed during the course of the relationship then gradually replaces this image over time. Aspects such as the exchange of information, a sincere concern for the customer's problems, and complying with the promises made, are issues to which suppliers should pay strict attention. Making promises that are impossible to keep is not a recommendable practice.

Cooperation can take many forms. Developing common research projects or promotion campaigns is a good option. Although collaboration can also be limited to the internal context of the relationship: when the customer has problems in its production process and the supplier shows an interest or offers advice to help overcome them, companies will appreciate this help very much, and their level of perceived satisfaction will rise considerably as a consequence.

Finally, commitment demonstrates the desire to keep the relationship alive. We understand that from the customer's point of view, when the supplier meets its expectations the customer's commitment to the relationship will grow. The supplier can demonstrate commitment by collaborating, dedicating time and staff to attend to the customer, or investing in specific assets, among other factors. In any case, these signals must be perceived by the other party for them to decide to orient their supply relationship towards the long-term.

However, the management of all these elements should consider the criterion of that customer's profitability, since from our point of view the relationship effort is not always justified. In cases where the customer is not attractive to the supplier, either currently or potentially, the relational orientation will be more suitable. Then, the effort will be concentrated on the firm's most attractive customers. The objective will be differentiation with respect to the competitors, demonstrating the supplier's interest in continuing the relationship by means of, for example, some of the measures described in this section.

As far as possible limitations of the study are concerned, we could perhaps mention the size of the sample. However, we are within the recommended limits (Hair et al., 1999) for applying the estimation method used here. Furthermore, our response rate of $23,53 \%$ allows us to be confident that the conclusions of this study are representative of the sector under analysis.

With regards the sector analyzed here, the agro-food sector presents a significant challenge to researchers for various reasons: the lack of previous work analyzing the relationships of these companies with their suppliers, the great heterogeneity in the characteristics defining the firms (size, ownership structure, managers' education and experience, and geographic markets), etc.

We should be cautious before generalizing our conclusions, and first analyze the degree of similarity of the sector of interest to the one analyzed in this work. 


\section{SUGGESTIONS FOR FUTURE RESEARCH}

Finally, one possible direction for future research would be to expand the study, analyzing other economic sectors and including new variables to increase the explanatory power of the model. We also suggest analyzing the moderating effects of size, experience, or economic sector, among others, in the hypotheses defining our model. Another line opened up by this work involves studying the long-term orientation of commercial relationships from the perspective of the supplier, or from that of both agents simultaneously. In this way, a complete dyadic perspective will be obtained.

\section{END NOTES}

1. There is not a complete sample that contains all Spanish wineries. Therefore, taking as reference data from the Spanish Agricultural, Fishing and Food Minister web and from the Regulatory Quality -Wines Boards we are creating a wide-random sample. We have started including the most relevant winery areas from Spain: Rioja, Navarra, Aragón, Cataluña, La Mancha... Both, production and geographical criteria have been followed in order to assure representativeness of this sample. But our research is already open. We would like to include all Spanish wineries in our database, but we recognize this is an arduous and slow work.

2. Moreover, the result of the non-parametric chi-square test produces a value 5,918 (3), associated with a pvalue of 0.116 , confirming that the sample is representative of the population object of study.

3. This indicator reflects the correlation of the item with the score of the scale, such that we eliminate those indicators with a total correlation under the minimum generally accepted value of 0,3 (Nurosis, 1993), or whose elimination significantly raises the Cronbach alpha. In any case, since empirical practice suggests a higher value (Hair et al., 1999), we use the threshold of 0,4.

\section{APPENDIX 1: MEASURING SCALES}

They have been translated from the Spanish version. All the scales ranges from 1 (the firm do not agree respect to our sentence) to 7 (the firm agree wit the sentence)

\section{TRUST}

T1. The supplier cares about my firm.

T2. The supplier has always been sincere with my firm.

T3. This supplier always keeps its promises.

T4. I can confide in this supplier when I share important information with it.

\section{COOPERATION}

C1. This supplier and I collaborate on certain points.

C2. Potential problems that arise are resolved cooperatively.

\section{COMMUNICATION/ INTERCHANGE OF INFORMATION}

INF1. My supplier and I share information.

INF2. Both parties are expected to keep the other informed about events or changes that may affect them.

INF3. The interchange of information is frequent and informal.

\section{SATISFACTION}

S1. Compared to our expectations, we are satisfied with this relationship.

S2. Compared to the ideal relationship, we are satisfied with this relationship.

S3. The supplier has fulfilled the promises it made at the beginning of the relationship.

S4. The relationship with this supplier is positive. 


\section{COMMITMENT}

CM1. I am willing to invest time and resources in the relationship with this supplier.

CM2. I will probably maintain or increase the business I give to this supplier.

CM3. I am willing to comply with the terms agreed with this supplier.

CM4. We have all conditions of the agreement clear. (Suppressed)

\section{LONG-TERM ORIENTATION}

OR1. I think that in the long term this relationship will be beneficial to my firm.

OR2. It is important for my firm to maintain this relationship in the future.

OR3. I am focusing on the long-term objectives of this relationship.

Appendix 2: Variance - Co-Variances Matrix $(\mathrm{N}=153)$

\begin{tabular}{||l|l|l|l|l|l|l|l|l|l|l|l|l|l|l|l|l|l|l|l||}
\hline & T1 & T2 & T3 & T4 & CP1 & CP2 & INF1 & INF2 & INF3 & S1 & S2 & S3 & S4 & CM1 & CM2 & CM3 & OR1 & OR2 & OR3 \\
\hline T1 & 1.23 & & & & & & & & & & & & & & & & & & \\
\hline T2 & 0.74 & 1.32 & & & & & & & & & & & & & & & & & \\
\hline T3 & 0.67 & 0.81 & 1.17 & & & & & & & & & & & & & & & & \\
\hline T4 & 0.60 & 0.87 & 0.62 & 1.26 & & & & & & & & & & & & & & & \\
\hline CP1 & 0.30 & 0.41 & 0.56 & 0.55 & 0.98 & & & & & & & & & & & & & & \\
\hline CP2 & 0.38 & 0.47 & 0.59 & 0.54 & 0.62 & 0.89 & & & & & & & & & & & & & \\
\hline INF1 & 0.49 & 0.69 & 0.60 & 0.68 & 0.50 & 0.62 & 1.77 & & & & & & & & & & & & \\
\hline INF2 & 0.45 & 0.61 & 0.58 & 0.69 & 0.56 & 0.51 & 0.88 & 1.34 & & & & & & & & & & & \\
\hline INF3 & 0.52 & 0.69 & 0.62 & 0.65 & 0.55 & 0.64 & 0.87 & 0.72 & 2.03 & & & & & & & & & & \\
\hline S1 & 0.36 & 0.57 & 0.51 & 0.48 & 0.65 & 0.46 & 0.49 & 0.60 & 0.49 & 1.14 & & & & & & & & & \\
\hline S2 & 0.39 & 0.61 & 0.53 & 0.44 & 0.48 & 0.48 & 0.58 & 0.57 & 0.45 & 0.69 & 1.09 & & & & & & & & \\
\hline S3 & 0.41 & 0.59 & 0.51 & 0.48 & 0.43 & 0.50 & 0.46 & 0.55 & 0.58 & 0.62 & 0.69 & 0.98 & & & & & & & \\
\hline S4 & 0.26 & 0.34 & 0.34 & 0.39 & 0.45 & 041 & 0.45 & 0.43 & 0.45 & 0.48 & 0.54 & 0.41 & 1.04 & & & & & & \\
\hline CM1 & 0.32 & 0.31 & 0.26 & 0.44 & 0.41 & 0.38 & 0.38 & 0.40 & 0.35 & 0.41 & 0.43 & 0.36 & 0.45 & 1.53 & & & & & \\
\hline CM2 & 0.33 & 0.29 & 0.27 & 0.31 & 0.32 & 0.25 & 0.33 & 0.37 & 0.36 & 0.26 & 0.35 & 0.38 & 0.34 & 0.65 & 1.06 & & & & \\
\hline CM3 & 0.37 & 0.26 & 0.24 & 0.29 & 0.26 & 0.22 & 0.36 & 0.32 & 0.30 & 0.34 & 0.28 & 0.38 & 0.28 & 0.47 & 0.66 & 0.99 & & & \\
\hline OR1 & 0.28 & 0.24 & 0.31 & 0.54 & 0.31 & 0.32 & 0.42 & 0.34 & 0.52 & 0.33 & 0.30 & 0.35 & 0.25 & 0.50 & 0.57 & 0.42 & 1.26 & & \\
\hline OR2 & 0.26 & 0.17 & 0.25 & 0.43 & 0.31 & 0.27 & 0.42 & 0.33 & 0.59 & 0.35 & 0.29 & 0.32 & 0.22 & 0.51 & 0.44 & 0.47 & 0.96 & 1.65 & \\
\hline OR3 & 0.31 & 0.28 & 0.27 & 0.45 & 0.29 & 0.22 & 0.40 & 0.44 & 0.53 & 0.24 & 0.25 & 0.27 & 0.20 & 0.46 & 0.45 & 0.51 & 0.95 & 1.06 & 1.86 \\
\hline N & 153 & 153 & 153 & 153 & 153 & 153 & 153 & 153 & 153 & 153 & 153 & 153 & 153 & 153 & 153 & 153 & 153 & 153 & 153 \\
\hline
\end{tabular}

\section{REFERENCES}

1. Achrol, R. and Stern, L., Environmental determinants of decisions-making uncertainty in marketing channels, Journal of Marketing Research, Vol.25, February, pp. 36-50, 1988.

2. Andaleeb, S., Dependence Relations and the Moderating Role of Trust: Implications for Behavioural Intentions in Marketing Channels, International Journal of Research in Marketing, Vol. 12, No. 2, pp. 157$172,1995$.

3. Andaleeb, S., An Experimental Investigation of Satisfaction and Commitment in Marketing Channels: The Role of Trust and Dependence, Journal of Retailing, Vol. 72, No. 1, pp. 77-93, 1996.

4. Anderson, J.C. and Gerbing, D., Structural Modelling in Practice: A Review and Recommended Two-Steps Approach, Psychological Bulletin, Vol. 10, No. 3, pp. 411-423, 1988.

5. Anderson, J. and Narus, J., A model of distributor firm and manufacturer firm working partnerships, Journal of Marketing, Vol. 54, January, pp. 42-58, 1990.

6. Anderson, E. and Weitz, B., The use of pledges to build and sustain commitment in distribution channels, Journal of Marketing Research, Vol. 14, pp.18-34, 1992.

7. Anderson, J., Hakansson, H. and Johanson, J., Dyadic business relationships within a business network context, Journal of Marketing, Vol. 58, October, pp. 1-15, 1994. 
8. Atuathene-Gima, K. and Li, H., When Does Trust matter? Antecedents and Contingent Effects of Supervisee Trust on Performance in Selling New Products in China and the United States, Journal of Marketing, Vol. 66, July, pp. 61-81, 2002.

9. Bagozzi, R., Evaluating structural equations models with unobservable variables and measurement error: a comment, Journal of Marketing Research, Vol. 18, pp. 375-381, 1981.

10. Bentler, P., EQS: Structural Equations Program Manual, Multivariate Software Inc., California, 1995.

11. Bentler, P. and Wu, E., EQS for Windows User's guide, Multivariate Software Inc, California, 1995.

12. Brennan, R. and Turnbull, P., Adaptative Behaviour in Buyer-supplier Relationships, Industrial Marketing Management, Vol. 28, pp. 481-495, 1999.

13. Baugmgartner, H. and Homburg, C., Applications of structural equation modelling in marketing and consumer research: a review, International Journal of Research in Marketing, Vol. 13, No. 3, pp. 139-161, 1996.

14. Cannon, J. and Perrault, W., Buyer-seller relationships in Business Markets, Journal of Marketing Research, Vol. 36, November, pp. 439-460, 1999.

15. Cannon, J. and Homburg, C., Buyer-supplier relationships and customer firm costs, Journal of Marketing, Vol. 65, January, pp. 29-43, 2001.

16. Churchill, G.A., A Paradigm for Developing Better Measures of Marketing Constructs, Journal of Marketing Research, Vol.1, No. 1, pp. 64-73, 1979.

17. Crosby, L., Laurence, A., Evans, K. and Cowles, D., Relationship Quality in Services Selling: An Interpersonal Influence Perspective, Journal of Marketing, Vol. 54, July, pp. 68-81, 1990.

18. Dabholkar, P., Johnston, W. and Cathey, A., The dynamics of long-term business-to-business exchange relationships, Journal of the Academy of Marketing Science, Vol. 22, No. 2, pp. 130-145, 1994.

19. Dahlstrom, R. and Nygaard, A., An empirical Investigation of Ex Post Transaction Cost in Franchised Distribution Channels, Journal of Marketing Research, Vol. 36, pp. 160-170, 1995.

20. De Wulf, K., Odekerken, G. and Iacobucci, D., Investments in consumer relationships: a cross-country and cross-industry exploration, Journal of Marketing, Vol. 65, October, pp. 33-50, 2001.

21. Donney, P. and Cannon, J., An examination of the nature of trust in buyer-seller relationships, Journal of Marketing, Vol. 61, April, pp. 35-51, 1997.

22. Dwyer, R., Schurr, P. and Oh, S., Developing buyer-seller relationships, Journal of Marketing, Vol. 51, April, pp. 11-27, 1987.

23. Ford, D., The development of buyer-seller relationship in industrial markets, European Journal of Marketing, Vol. 14, No. 5,6, pp. 339-353, 1980.

24. Ganesan, S., Determinants of Long Term Orientation in Buyer-Seller Relationships, Journal of Marketing, Vol. 58, April, pp. 1-19, 1994.

25. Garbarino, E. and Johnson, M., The different roles of satisfaction, trust and commitment in customer relationships, Journal of Marketing, Vol. 63, April, pp. 70-87, 1999.

26. Geykens I., Steenkamp, J. and Kumar, N. The effects of trust and interdependence on relationship commitment: A trans-Atlantic study, International Journal of Research in Marketing, Vol. 13, pp. 303-317, 1998.

27. Grönroos, C., Relationship Marketing: Strategic and Tactical Implications, Management Decisions, Vol. 3, No. 3-4, pp. 5-14, 1996.

28. Grönroos, C., Relationship marketing: interaction, dialogue and value, Revista Europea de Dirección y Economía de la Empresa, Vol. 9, No. 3, pp. 13-24, 2000.

29. Gummerson, E., The New Marketing. Developing Long Term Interactive Relationship, Long Range Planning, Vol. 20, No. 4, pp.10-20, 1987.

30. Gundlach, G., Achrol, R. and Mentzer, J., The Structure of Commitment in Exchange, Journal of Marketing, Vol. 59, January, pp. 78-92, 1995.

31. Hair, J., Tatham, R. and Black, W., Análisis multivariante, Prentice-Hall, 1999.

32. Hallen, L., Johanson, J. and Seyed-Mohamed, N., Interfirm adaptation in business relationships, Journal of Marketing, Vol. 55, April, pp. 29-37, 1991.

33. Handfield, R. and Betchel, C., The role of trust and relationship structure in improving supply chain responsiveness, Industrial Marketing Management, Vol. 31, No. 4, pp. 367-382, 2002.

34. Hansen, S., Swan, J. and Powers, T., Encouraging "friendly" complaint behaviour in industrial markets: 
preventing a loss of customers and reputation, Industrial Marketing Management, Vol. 25, No. 4, pp. 271$281,1996$.

35. Heide, J. and John, G., Alliances in Industrial Purchasing: The Determinants of Joint Action in BuyerSupplier Relationships, Journal of Marketing Research, Vol. 52, January, pp. 20-35, 1990.

36. Heide, J., Interorganizational governance in marketing channels, Journal of Marketing, Vol. 58, January, pp. $71-85,1994$.

37. Hewett, K., Money, B. and Sharma, S., An Exploration of the Moderating Role of Buyer Corporate Culture in Industrial Buyer-Seller Relationships, Journal of the Academy of Marketing Science, Vol. 30, No. 3, pp. 229-239, 2001.

38. Hogan, J., Expected relationship value: a construct, a methodology for measurement and a modelling technique, Industrial Marketing Management, Vol. 30, No. 4, pp. 339-351, 2001.

39. Hunt, S., Wood, V. and Chonko, L., Corporate ethical values and organizational commitment in marketing, Journal of Marketing, Vol. 53, July, pp. 79-90, 1989.

40. Iglesias, V. and Vázquez, R., The Moderating Effect of Exclusive Dealing Agreements on Distributor Satisfaction, Journal of Strategic Marketing, Vol. 9, No. 3, pp. 215-231, 2001.

41. Jap, S. and Ganesan, S., Control Mechanisms and the Relationship Life Cycle: Implications for Safeguarding Specific Investments and Developing Commitment, Journal of Marketing Research, Vol. 37, May, pp. 227245, 2000.

42. Johnson, J., Strategic integration in industrial distribution channels: managing the interfirm relationships as a strategic asset, Journal of the Academy of Marketing Science, Vol. 27, No. 1, pp. 4-18, 1999.

43. Kalafatis, S., Buyer-seller relationships along channels of distribution, Industrial Marketing Management, Vol. 31, No. 3, pp. 215-228, 2002.

44. Kim, K. and Frazier, G., Measurement of Distributor Commitment in Industrial Channels of Distribution, Journal of Business Research, Vol. 40, pp. 139-154, 1997.

45. Kohli, A. and Leuthesser, L., Relational behaviour in business markets, Journal of Business Research, Vol. 34, pp. 221-233, 1995.

46. Kothandaraman, P. and Wilson, D., The future of competition: value-creating networks, Industrial Marketing Management, Vol. 30, No. 4, pp. 379-389, 2001.

47. Kumar, N., Scheer, L. and Steenkamp, J., The effects of supplier fairness on vulnerable resellers, Journal of Marketing Research, Vol. 32, February, pp. 54-65, 1995a.

48. Kumar, N., Scheer, L. and Steenkamp, J., The effects of perceived interdependence on dealer attitudes, Journal of Marketing Research, Vol. 32, August, pp. 348-356, 1995 b.

49. Leek, S., Naudé, P. and Turnbull, W., Interactions, relationships and networks in a changing world, Industrial Marketing Management, Vol. 32, No. 2, pp. 87-90, 2003.

50. Lemon, K., Barnett, T. and Winer, R., Dynamic customer relationship management: incorporating future considerations into the service retention decision, Journal of Marketing, Vol. 66, January, pp. 1-14, 2002.

51. Leuthesser, L., Supplier relational behaviour: an empirical assessment, Industrial Marketing Management, Vol. 26, pp. 245-254, 1997.

52. Li, Z., Communication in Marketing Channels: Moderating effects of Power Structure and Relationalism, Journal of Marketing Channels, Vol. 6, No. 3-4, pp. 45-71, 1998.

53. Mohr, J. and Nevin, J., Communication strategies in marketing channels: a theoretical perspective, Journal of Marketing, Vol. 54, October, pp. 36-51, 1990.

54. Mohr, J. and Spekman, R., Characteristics of Partnership Success: Partnerships Attributes, Communications Behaviour and Conflict Resolution Techniques, Strategic Management Journal, Vol. 15, pp. 135-152, 1994.

55. Mohr, J. and Soshi, R., Communications Flows in Distribution Channels: Impact on Assessments of Communications quality and Satisfaction, Journal of Retailing, Vol. 71, No. 4, pp. 393-416, 1995.

56. Mohr, J., Fischer, R. and Nevin, J., Collaborative communication in interfirm relationships: moderating effects of integration and control, Journal of Marketing, Vol. 60, July, pp. 103-115, 1996.

57. Morgan, R. and Hunt, S., The commitment-trust theory of relationship marketing, Journal of Marketing, Vol. 58, July, pp. 20-38, 1994.

58. Moorman, C., Deshpandé, R. and Zaltman, G., Factors affecting trust in market research relationships, Journal of Marketing, Vol. 57, January, pp. 81-101, 1992.

59. Nunnally, J., Psychometric Theory, McGraw-Hill, New York, 1979. 
60. Nunnally, J. and Bernstein, I.H., Psychometric Theory, $3^{\text {a }}$ Edición, McGraw-Hill, NY, 1994.

61. Nurosis, M., SPSS. Statistical Data Analysis, SPSS Inc, 1993.

62. Rexha, N., Integrating Relationship marketing activities with offering quality in the supplier's relational marketing program, Journal of Business to Business Marketing, Vol. 7, No. 1, pp. 1-17, 2000.

63. Sharland, A., The negotiation process as a predictor of relationship outcomes in international buyer-supplier arrangements, Industrial Marketing Management, Vol. 30, No. 7, pp. 551-559, 2001.

64. Sharma, A., Krishnan, R. and Grewal, D. Value Creation in Markets: a critical area of focus for business-tobusiness markets, Industrial Marketing Management, Vol. 30, No. 4, pp. 391-402, 2001.

65. Siguaw, J., Simpson, P. and Baker, T., Effects of supplier market orientation on distributor market orientation and the channel relationship: the distributor perspective, Journal of Marketing, Vol. 62, July, pp. 99-111, 1998.

66. Speckman, R., Strategic Supplier Selection: Understanding Long Term Buyer Relationships, Business Horizons, July-August, pp. 75-81, 1988.

67. Thomas, J., A methodology for linking customer acquisition to customer retention, Journal of Marketing Research, Vol. 38, February, pp. 262-268, 2001

68. Tikkanen, H., Alajoutsijärvi, K. and Tähtinen, J., The concept of satisfaction in industrial markets: a contextual perspective and a case study from the software industry, Industrial Marketing Management, Vol. 29, pp. 373-386, 2000.

69. Tuten, T. and Urban, D., An expanded model of business-to-business partnership formation and success, Industrial Marketing Management, Vol. 30, No. 2, pp. 149-164, 2001.

70. Turnbull, P. and Wilson, D., Developing and protecting profitable customer relationships, Industrial Marketing Management, Vol. 18, No. 3, pp. 233-238, 1989.

71. Van der Haar, J., Kemp, R. and Omta, O., Creating value that cannot be copied, Industrial Marketing Management, Vol. 30, pp. 627-636, 2001.

72. Walter, A., Ritter, T. and Gemünden, H., Value Creation in Buyer-seller relationships, Industrial Marketing Management, Vol. 30, No. 4, pp. 365-377, 2001.

73. Walter, A., Müller, T., Helfert, G. and Ritter, H., Functions of industrial supplier relationships and their impact on relationship quality, Industrial Marketing Management, Vol. 32, No. 2, pp. 159-169, 2003.

74. Wathne, K. and Heide, J., Opportunism in interfirm relationships: forms, outcomes, and solutions, Journal of Marketing, Vol. 64, October, pp. 36-51, 2000.

75. Wilson, D., An integrated model of buyer-seller relationships, Journal of the Academy of Marketing Science, Vol. 23, No. 4, pp. 335-345, 1995. 


\section{NOTES}

